\title{
HETEROGENEOUS IMPACT OF QUANTITATIVE EASING ON GOVERNMENT BOND YIELDS
}

\author{
Mesut Turkay, Timur Han Gur*
}

\begin{abstract}
Interest rates in many advanced countries have reached zero lower bound and this has led to the widespread use of unconventional monetary policies after the global crisis. Hence, it has been more and more important to better understand the effects of these policies on major economic variables and the transmission mechanism through which they influence the economy. This study analyses the impact of quantitative easing (QE) policies on local currency government bond yield in emerging market (EM) economies in a heterogeneous panel setting. An Augmented Mean Group (AMG) estimator is used that allows for cross-sectional dependence and heterogeneous slopes. Model results show that government bond interest rates in EM economies are determined by country-specific factors such as central bank policy rate, inflation and budget deficit as well as external global factors such as US ten-year government bond yield and QE policies of advanced countries' central banks.
\end{abstract}

Keywords: Unconventional monetary policy, Quantitative easing, Augmented Mean Group JEL Classification: C23, E43, E52

\section{Introduction}

In response to the global economic crisis of 2008-09, which is considered by many scholars the worst crisis since the Great Depression, the Federal Reserve (Fed) first employed the conventional interest rate tool of monetary policy and lowered the policy rate until it reached zero lower bound (ZLB). Upon reaching the ZLB, the Fed started to implement unconventional monetary policies. In particular, three rounds of quantitative easing (QE) programmes were conducted that included mainly the purchases of government securities and mortgage-backed securities. Other leading central banks also followed the Fed to carry out unconventional monetary policies in the post-crisis period and there has been a huge explosion of global liquidity.

Due to low growth and inflation outlook and policy rates at the zero lower bound for many advanced economies, unconventional monetary policies have been increasingly used in the post-crisis period and have become the new normal. Hence, it has been more and more important to understand the transmission mechanism of unconventional monetary policies and the spillover effects of these policies on both domestic and international economic indicators. This is one crucial reason that motivates us to conduct an empirical study on the spillovers of quantitative easing policies.

* Mesut Turkay, Undersecretariat of Treasury, Republic of Turkey, Ankara, Turkey (mesut.turkay@hazine.gov.tr)-corresponding author;

Timur Han Gur, Department of Economics, Hacettepe University, Ankara, Turkey

(timurgur@hacettepe.edu.tr). 
There are several studies concerning the impact of unconventional monetary policies on major economic variables of the country where these policies are implemented. However, evidence on the international spillovers of these policies is still somewhat limited. More research is needed to shed light on international spillover effects of unconventional monetary policies and this is another motivation of the study.

Despite the growing size (from $\$ 1.3$ trillion in 2000 to $\$ 7$ trillion in 2015) and thus importance of Emerging Market (EM) local currency sovereign debt, there are only a few studies on the determinants of local EM government bond yield. We contribute to the literature by both modelling local government bond yields in EM economies and analysing the impact of QE on the yields. While other studies in the literature assume homogeneous slope coefficients and cross-sectional independence, we use an Augmented Mean Group (AMG) estimator that allows for slope heterogeneity and cross-sectional dependence. Since almost all of the real-world data contain slope heterogeneity and cross-sectional dependence, this method provides more consistent and unbiased results compared to others. In addition, it also gives country-specific slope coefficients. Analysing the heterogeneity of international spillovers of QE policies across countries is an important contribution of the study vis-a-vis existing studies.

In this study, we analyse the effect of QE policies implemented in the US on government bond yields of emerging market economies. The remainder of this study is organised as follows: In Section 2 we provide the related literature. Section 3 contains our data set and empirical methodology. Section 4 reports the model results, Section 5 includes a robustness analysis and Section 6 concludes.

\section{Literature Review}

The literature regarding the effects of quantitative easing policies on the economy has grown rapidly especially with the widespread implementation of these policies after the global economic crisis in 2008. There are various studies about the effects of QE both on financial markets and real sector variables. Many of the studies in the related literature focus on the impact of QE on long-term interest rates.

There are several studies concerning the effects of QE on both domestic and international long-term interest rates. However, those on domestic interest rates are more common. Among the studies related to the US, Gagnon et al. (2011) use event study methodology and find the effect of QE1 on 10-year government bond yield as 91 basis points (bps). Wright (2012) applies a Structural Vector Autoregression (SVAR) model and finds out that asset purchases in the US lower government bond yields but the effect dies out in a few months. D'Amico and King (2013) estimate the stock effect of bond purchases under QE1 as 30 bps on long-term bond yields and flow effects as $3.5 \mathrm{bps}$ on the day of the purchase.

Looking at the studies that analyse the impact of QE in the UK, Joyce et al. (2011) find that asset purchases reduce long-term bond yields by $100 \mathrm{bps}$ using several methods such as event study, portfolio balance and VAR models. According to Joyce and Tong (2012), the effect of QE announcement on bond yield is up to $120 \mathrm{bps}$. Among studies that 
investigate the effects of asset purchases in the Euro Area, Szczerbowicz (2015) finds out by using event study methodology that ECB bond purchases reduced sovereign spreads and refinancing costs of banks. Eser and Schwaab (2016) analyse the impact of SMP on 5-year bond yield and find that the estimates vary from -1 to -2 bps for Italy to -17 to $-21 \mathrm{bps}$ for Greece per $€ 1$ billion bond purchase. From the studies concerning the impact of QE in Japan, Bernanke et al. (2004) estimate that QE in Japan lowers bond yield by 50 bps. Kimura and Small (2006) argue that the portfolio balance effect of QE is significant, while Oda and Ueda (2007) claim that the portfolio rebalancing effect is insignificant and the signaling effect is significant.

Studies related to international spillover effects of QE on long-term government bond yields are relatively rare. Among them, Bauer and Neely (2014) investigate the channels through which the Federal Reserve's asset purchases affect international bond yields. According to the model results, the signaling effect is strong for the US and Canada, while the portfolio balance channel is relatively more influential for Australia and Germany compared to the US and Canada. Neely (2015) investigates the announcement effects of QE1 implemented in the US on 10-year bond yields of major advanced economies. Accordingly, the impact ranges from $18 \mathrm{bps}$ for Japan to $100 \mathrm{bps}$ for the US. Bowman et al. (2015) apply a VAR model to investigate the announcement effects of US unconventional monetary policy and find that it reduces bond yields in EM economies. Fratzscher et al. (2016) analyse the effects of the Fed's QE1 and QE2 on 42 emerging and 21 advanced economies' financial markets. They find out that QE1 was effective in reducing sovereign bond yields and boosting equities globally. On the other hand, QE2 increased equities worldwide but had little impact on yields. Georgiadis and Gräb (2016) study the announcement impact of the ECB's extended asset purchase programme (EAPP) on global financial markets. Results imply that the announcement had a limited impact on bond prices and the effect is significant only for the Euro Area, Japan and emerging Asia. Tillmann (2016) proposes a Qual VAR model to study the effects of QE in the US on EM financial indicators and finds significant impact on exchange rates, bond and equity prices. The influence of QE1 on bond yields is limited compared to that of QE2 and QE3. Chen et al. (2016) put forward that international spillovers vary across countries and time. Effects on EM countries are larger than those on advanced countries. QE policies implemented by the US supported recovery in EM countries in 2009 and 2012, but also led to overheating in China, Brazil and some other EM countries in 2010 and 2011. Potjagailo (2017) analyses the spillover effects of ECB unconventional monetary policy by using a FAVAR model and finds that monetary policy expansion leads to higher production and lower uncertainty and short-term interest rates. The spillovers vary with country characteristics such as trade openness, financial integration and exchange rate regime. Horvath and Voslarova (2017) analyse the impact of the ECB's unconventional monetary policy using panel vector autoregressions. Model results imply that expansionary unconventional monetary policy shocks lead to a temporary increase in output and inflation in Central Europe.

Since we model domestic government bond interest rates of EM economies in this study, it is useful to provide a brief literature review on the determinants of government 
bond yields. Much of the earlier literature on the pricing of sovereign bonds in emerging market economies focus on the determinants of bond spreads relative to some "safe" bonds, most often US bonds. These are the bonds denominated in foreign currency. Uribe and Yue (2006), Ebner (2009), Comelli (2012) and Csonto (2014) are among some of these studies. These studies in general find out that both country macroeconomic fundamentals and global factors such as ample liquidity and world interest rates affect bond spreads in EM economies.

Even though there are several studies on the determinants of sovereign bond spreads in emerging market economies, there is a scarcity of work on the drivers of domestically issued bond yields despite their growing importance. Peiris (2010) performs a panel analysis of $10 \mathrm{EM}$ economies and estimates that the effect of a 1 percent increase in the fiscal balance to GDP ratio on bond yields is about 20 bps. Other significant determinants of bond yields include policy interest rates, foreign participation in domestic bond markets and inflationary expectations. Baldacci and Kumar (2010) use panel data for 31 advanced and emerging economies for 1980-2008 and find that higher budget deficits, debt and central bank rates increase sovereign bond yields. Jaramillo and Weber (2013) apply a panel threshold model to analyse the determinants of domestic sovereign bond yields. The results of the study imply that when global risk aversion is low, countryspecific fundamentals such as inflation and growth are the most important drivers of bond yield. On the other hand, when risk aversion is high, fiscal deficit and government debt take the center stage. Miyajima et al. (2015) show that central bank policy rates, GDP growth and fiscal balance are the most important determinants of local currency bond yields in EM economies.

\section{Methodology and Data}

Early literature on panel data ignored cross-sectional dependence of errors and assumed homogeneous slopes. Studies in this tradition typically used fixed and random effect estimators that perform an instrumental variable technique and the generalised method of moments (GMM) estimators. These models only allow the intercepts to vary across countries and impose a high degree of homogeneity that is not very realistic. One important contribution has been the introduction of first-generation panel time series estimators that allow for heterogeneity in the slope coefficients such as Mean Group (Pesaran and Smith, 1995) and Pooled Mean Group (Pesaran et al., 1999). Although these estimators allow for heterogeneity, they are found to be inconsistent in the presence of cross-sectional dependence. Another significant contribution to the panel time series literature has been the development of estimators that are robust to both heterogeneity and cross-sectional dependence. These include Common Correlated Effects (Pesaran, 2006) and Augmented Mean Group (Eberhardt and Bond, 2009; Eberhardt and Teal, 2011) estimators.

In our study, we use monthly data that cover the period from 2006:1 to 2015:12 for 17 emerging market economies. The countries included in the study are: Brazil, China, 
Hungary, Colombia, Czech Republic, Indonesia, Mexico, Malaysia, Turkey, South Africa, Korea, Philippines, Poland, Thailand, India, Singapore and Taiwan. Data on industrial production and consumer price index are taken from the World Bank Global Economic Monitor database. Data on budget deficit, debt stock and current account deficit are taken from the World Economic Outlook Database. Domestic government bond yield, central bank policy interest rate, VIX Index, 10-year US government bond yield and quantitative easing variables are obtained from Bloomberg.

This section proceeds in four steps. First, we test for the presence of cross-sectional dependence in our data. Second, a panel unit root test is conducted to identify the nature of stationarity of the variables. Third, we test for slope heterogeneity. Fourth, an Augmented Mean Group (AMG) estimator is employed to model long-term domestic government bond yields in EM economies and analyse the impact of quantitative easing on long-term government bond yields.

\subsection{Cross-sectional dependence}

Cross-sectional dependence has become the rule rather than the exception due to strong interdependencies among countries resulting from globalisation and common shocks such as economic crises and oil shocks. First-generation estimators, panel unit root and cointegration tests that assume cross-sectional independence are inadequate and may lead to significant size distortions, misleading inference and inconsistent estimators in case cross-sectional dependence exists (Chudik and Pesaran, 2013). Therefore, it is vital to test for cross-sectional dependence and use second-generation tests and estimators in case cross-sectional dependence exists.

A number of tests have been developed for cross-sectional dependence and we use two of them that are common in the literature. The first one is Pesaran's (2004) CD test. The CD test is applicable when the cross-sectional dimension $(N)$ is larger than the time series dimension (T). The CD test statistic proposed in Pesaran (2004) is calculated as follows:

$$
C D=\sqrt{\frac{2 T}{N(N-1)}}\left(\sum_{i=1}^{N-1} \sum_{j=i+1}^{N} \hat{\rho}_{i j}\right) \sim N(0,1) \quad i, j=1,2,3, \ldots \ldots, N
$$

where $\hat{\rho}_{i j}$ is the sample estimate of the pairwise correlation of the residuals obtained by OLS. The second cross-sectional dependence test we employ is the bias-adjusted LM test developed by Pesaran et al. (2008). This test is applicable when the number of crosssectional units $(N)$ is small compared to the time dimension $(T)$ and can be employed even when the CD test is inconsistent. It is calculated as:

$$
L M^{*}=\sqrt{\frac{2 T}{N(N-1)}}\left(\sum_{i=1}^{N-1} \sum_{j=i+1}^{N} \hat{\rho}_{i j}\right) \frac{(T-k) \hat{\rho}_{i j}{ }^{2}-E(T-k) \hat{\rho}_{i j}{ }^{2}}{\operatorname{Var}(T-k) \hat{\rho}_{i j}{ }^{2}}
$$

Results of the CD and bias-adjusted LM tests are provided in Table 1. 
Table 1 | Cross-sectional Dependence Test Results

\begin{tabular}{|l|c|c|}
\hline Variable & CD test & Bias-adjusted LM test \\
\hline GIR & $42.94^{* * *}$ & $896.3^{* * *}$ \\
\hline CBI & $13.81^{* * *}$ & $888.1^{* * *}$ \\
\hline INF & $13.24^{* * *}$ & $869.4^{* * *}$ \\
\hline IND & $24.69^{* * *}$ & $872.5^{* * *}$ \\
\hline CAD & $14.64^{* * *}$ & $899.8^{* * *}$ \\
\hline BDEF & $57.72^{* * *}$ & $902.0^{* * *}$ \\
\hline DEBT & $36.15^{* * *}$ & $901.0^{* * *}$ \\
\hline
\end{tabular}

Note: ${ }^{*},{ }^{* *},{ }^{* *}$ show significance at the $10 \%, 5 \%$ and $1 \%$ confidence level, respectively. The null hypothesis is no cross-sectional dependence for both tests. GIR denotes domestic government bond yield, CBI is central bank policy rate, INF is year-on-year headline inflation rate, IND is year-on-year growth of industrial production, CAD is current account deficit to GDP ratio, BDEF is budget deficit to GDP ratio and DEBT implies gross debt stock to GDP ratio.

Source: Author's calculations.

According to Table 1, both tests reject the null hypothesis of cross-sectional independence at the 1 percent level for all series under consideration and imply that cross-sectional dependence exists. Therefore, we have to use second-generation unit root tests and estimators that take into consideration cross-sectional dependence.

\subsection{Unit root test}

We use a second-generation CIPS (Pesaran, 2007) panel unit root test since cross-sectional dependence exists. In this unit root test, ADF regression is augmented with the lag of cross-sectional mean and its first difference. It is called a cross-sectionally augmented Dickey-Fuller (CADF) test and the equation is provided below.

$$
y_{i, t}=\alpha_{i}+\gamma_{i} y_{i, t-1}+\ldots \ldots+\delta_{i 0} \bar{y}_{t}+\delta_{i 1} \bar{y}_{t-1}+\ldots \ldots+\delta_{i p} \bar{y}_{t-p}+\epsilon_{i, t}
$$

In order to get the CIPS statistic, Equation 3 is converted into a first difference and individual $\mathrm{ADF}$ statistics $\left(C A D F_{i}\right)$ are calculated for cross-sections. We obtain the CIPS statistic as:

$$
C I P S=\frac{\sum_{i=1}^{\mathrm{N}} C A D F_{i}}{N}
$$

The null hypothesis of the test is the unit root and critical values are reported in Pesaran (2007). Table 2 provides the results of the panel unit root test. Accordingly, government interest rate, central bank policy rate, inflation rate and growth of industrial production are stationary in their level form ${ }^{1}$. Budget deficit, public debt stock and current account deficit as percent of GDP are found to be I(1).

$\overline{1}$ Since the variables do not have a trend, we take into consideration unit root test results with only intercept. 
Table 2 | Panel Unit Root Test Results

\begin{tabular}{|l|c|c|l|l|c|}
\hline \multirow{2}{*}{} & \multicolumn{5}{|c|}{ CIPS test } \\
\cline { 2 - 6 } & Intercept & $\begin{array}{c}\text { Intercept } \\
+ \text { trend }\end{array}$ & \multicolumn{2}{|c|}{ Intercept } & $\begin{array}{c}\text { Intercept } \\
+ \text { trend }\end{array}$ \\
\hline GIR & $-2.047^{* *}$ & -0.929 & $\Delta G I R$ & $-19.43^{* * *}$ & $-19.19^{* * *}$ \\
\hline CBI & $-1.585^{*}$ & 1.864 & $\Delta C B I$ & $-16.71^{* * *}$ & $-16.18^{* * *}$ \\
\hline INF & $-2.905^{* * *}$ & -1.104 & $\Delta I N F$ & $-19.15^{* * *}$ & $-18.86^{* * *}$ \\
\hline IND & $-7.459^{* * *}$ & $-7.866^{* * *}$ & $\Delta I N D$ & $-20.16^{* * *}$ & $-20.17^{* * *}$ \\
\hline BDEF & -0.027 & $-3.018^{* * *}$ & $\Delta B D E F$ & $110.8^{* * *}$ & $69.7^{* * *}$ \\
\hline DEBT & -0.507 & -0.237 & $\Delta D E B T$ & $-1.895^{* *}$ & -0.568 \\
\hline CAD & 0.638 & -0.481 & $\Delta C A D$ & $-4.173^{* * *}$ & $-1.997^{* *}$ \\
\hline
\end{tabular}

Note: ${ }^{* * *},{ }^{* * *}$ show significance level at $10 \%, 5 \%$ and $1 \%$, respectively.

Source: Author's calculations.

However, since the data period we cover includes the global economic crisis of 2008-09, it is highly probable that there are structural breaks in the data. Therefore, we use a panel unit root KPSS test (PANKPSS) introduced by Carrion-i-Silvestre et al. (2005), which allows for both cross-sectional dependence and structural breaks. Test results in Table 3 imply that budget deficit and current account deficit to GDP ratio are stationary.

Table 3 | Panel KPSS Test Results

\begin{tabular}{|l|c|c|}
\hline Variable & Test statistics & $p$-value \\
\hline BDEF (hom) & -1.52 & 0.936 \\
\hline BDEF (het) & -0.89 & 0.814 \\
\hline CAD (hom) & -1.61 & 0.946 \\
\hline CAD (het) & -0.11 & 0.543 \\
\hline DEBT (hom) & 1.49 & 0.067 \\
\hline DEBT (het) & 1.63 & 0.051 \\
\hline
\end{tabular}

Notes: Bootstrap critical values are used due to the presence of cross-sectional dependence. Hom in brackets refers to the test statistics under the homogeneity of long run variance and het refers to the test statistics under the heterogeneity of long-run variance.

Source: Author's calculations.

We use the Ng-Perron (2001) unit root test to investigate whether cross-sectionally invariant variables are stationary. The results show that the VIX index and bond purchases 
are stationary while the ten-year US government bond yield is I(1) and we use the first difference of the variable ${ }^{2}$.

\subsection{Slope homogeneity test}

Many empirical studies that use panel data assume homogeneous slopes and heterogeneity across units is confined to unit-specific intercepts. However, as Pesaran and Smith (1995) and many others point out, the assumption of slope homogeneity is usually inappropriate. Monte Carlo experiments show that the homogeneous slope estimators can be seriously biased and produce inconsistent and misleading results in the presence of slope heterogeneity (Chudik and Pesaran, 2015). Therefore, it is vital to test for slope homogeneity and use estimators that are robust to slope heterogeneity in case slope homogeneity is rejected.

In order to test for slope homogeneity, we employ the test introduced by Pesaran and Yamagata (2008), which allows for cross-sectional dependence. Table 4 provides the results of the slope homogeneity test. Accordingly, the null hypothesis of slope homogeneity is rejected.

Table 4 | Slope Homogeneity Test Results

\begin{tabular}{|l|c|}
\hline & Value \\
\hline Swamy $\hat{S}$ & $1,149.6^{* * *}$ \\
\hline$\tilde{\Delta}$ & $899.1^{* * *}$ \\
\hline$\tilde{\Delta}_{\text {adj }}$ & $947.3^{* * *}$ \\
\hline$\hat{\Delta}$ & $57.0^{* * *}$ \\
\hline$\hat{\Delta}_{\text {adj }}$ & 0.50 \\
\hline
\end{tabular}

Note: ${ }^{*},{ }^{* *},{ }^{* *}$ show that test statistics are significant at the $10 \%, 5 \%$ and $1 \%$ significance level, respectively. The null hypothesis is slope homogeneity.

Source: Author's calculations.

\subsection{Interest rate model}

Slope homogeneity and cross-sectional dependence tests imply that the series have cross-sectionally dependent errors and slope heterogeneity. Therefore, we use the Augmented Mean Group (AMG) estimator, which allows for cross-sectional dependence and slope heterogeneity ${ }^{3}$. Consider the following panel model:

$2 \quad$ Results are available upon request.

3 We also tried a Common Correlated Effects (CCE) estimator. Model results are more or less similar to those with the Augmented Mean Group (AMG) estimator. Bond and Eberhardt (2013) show that the AMG estimator performs similarly to the CCE estimator. 


$$
\begin{gathered}
y_{i t}=\beta_{i} x_{i t}+u_{i t} \\
\text { where } u_{i t}=\alpha_{1 i}+\lambda_{i} f_{t}+\varepsilon_{i t} \\
x_{i t}=\alpha_{1 i}+\lambda_{i} f_{t}+\varphi_{i} g_{t}+e_{i t}
\end{gathered}
$$

Where $x_{i t}$ and $y_{i t}$ are observables, $\beta_{i}$ is a country-specific slope parameter, $u_{i t}$ implies unobservables and $\varepsilon_{i t}$ is the error term. $\alpha_{1 i}$ shows group fixed effects that capture timeinvariant heterogeneity. $f_{t}$ is an unobserved common factor with heterogeneous factor loadings $\lambda_{i}$ and captures cross-sectional dependence and time-variant heterogeneity.

In our benchmark specification, the dependent variable $y_{i t}$ is the 10 -year local currency government bond yield of the related country. The explanatory variables $x_{i t}$ are grouped in three sets: country-specific variables that affect government bond yield, common global variables that influence all of the countries, and quantitative easing variables.

According to the term structure of interest rates theory, long-term government bond yields consist of expected future short-term interest rates and a term premium. Central bank policy rate is one significant variable that affects both short-term interest rate and expected future short-term interest. Policy rate hikes increase long-term interest rates by bumping up current short-term rates and expectations of future short-term rates. Since we do not have enough information on expected policy rates, we use current central bank policy rate as a proxy. Inflation and economic growth are other crucial determinants of government bond yields. Higher inflation and growth rates tend to boost both short and long-term interest rates. Inflation is used to control for the Fisher effect and GDP growth is included to control for the cyclical position of the country. We use year-on-year change of consumer price index as inflation and year-on-year growth in industrial production as a proxy for economic activity. Current account balance to GDP ratio is used to control for external vulnerabilities and currency risk. As for fiscal variables, we use budget deficit to GDP ratio and gross public debt stock to GDP ratio. There is a broad body of literature that shows government interest rates and spreads going up as budget deficit and debt stock rises. In line with the literature, we use budget deficit to GDP ratio in its level form and debt stock to GDP ratio in its firstdifference form.

As for the common global variables, following previous studies including Comelli (2012) and Csonto (2014), we use the 10-year US government bond yield and the VIX index. The 10-year US bond yield is used as a measure of global liquidity conditions and reflects the international financing conditions and global financing costs. The 10-year US bond yield is expected to have a positive relationship with bond yields in EM economies. The VIX is an index that refers to average option-implied volatility on the S\&P500 index and is used extensively as a measure of global uncertainty and risk appetite. It is expected to have a positive sign because a rise in risk aversion raises the yields demanded by investors to hold EM debt securities.

The literature shows that both announcements regarding quantitative easing programmes and actual purchases by the Federal Reserve (Fed) affected interest rates. Therefore, 
in order to investigate the effect of US quantitative easing on sovereign bond yields in EM economies, we include both actual bond purchases by the Federal Reserve in the related period in billions of dollars and dummy variables to analyse announcement effects. We build 3 different dummy variables for QE1, QE2 and QE3 so as to find announcement effects of the programmes separately. Dummy variables take the value one in months when the Fed announces or expands a QE programme. ${ }^{4}$

\section{Empirical Results}

Table 5 presents benchmark model results. We first estimate a parsimonious model (Column 1) where only country-specific explanatory variables are included. The results show that central bank rate, inflation and budget deficit are significant determinants of long-term domestic government bond yield in EM economies. Accordingly, a 1 percentage point rise in policy rate increases government bond interest rates by about $37 \mathrm{bps}$. A 1 percent deterioration in budget deficit to GDP ratio boosts government interest rates by 11 bps. Industrial production, current account deficit to GDP ratio and change in public debt stock to GDP ratio are not significant.

In the second model (Column 2) we also include global common variables (VIX index and 10-year US bond yield) in addition to country-specific variables. Results are similar to those of the first model. The VIX index is not significant and the impact of a 1 percentage point increase in 10-year US government bond yield on EM government interest rate is about 50 bps. This shows the importance of US government bond yield as a determinant of interest rates in emerging markets. The third model (Column 3) includes QE variables in addition to country-specific and global common variables. Results imply that bond purchases by the Federal Reserve are a significant determinant of EM government bond yield. According to the model, 100 billion dollars' worth of bond purchases lowers government bond yield in EM economies by about 20 bps on average. Announcements of QE programmes also lead to a fall of EM bond yields. However, only the announcements related to QE3 are found to be significant.

The results show that local government bond yields in EM economies are determined by country-specific variables, global common and QE variables. Both the significance and coefficients of the variables are similar to those of the previous studies. Central bank interest rates, inflation and budget deficit in the country are significant determinants of bond yield in line with Peiris (2010), Baldacci and Kumar (2010) and Miyajima et al. (2015). The 10-year US bond interest rate is a significant determinant similarly to Comelli (2012) and Csonto (2014). Likewise, D’Amico and King (2013), Neely (2015) and Georgiadis and Gräb (2016) found that announcements about the QE programmes and actual bond purchases by the Fed affect EM government bond yields significantly.

$4 \quad$ Details of the announcement dates for QE1, QE2 and QE3 may be provided upon request. 
Table 5 | Baseline Model for Domestic Government Interest Rates

\begin{tabular}{|c|c|c|c|}
\hline Explanatory variables & Model 1 & Model 2 & Model 3 \\
\hline Central Bank Rate & $\begin{array}{l}0.372^{* * *} \\
(0.063)\end{array}$ & $\begin{array}{l}0.396^{* * *} \\
(0.059)\end{array}$ & $\begin{array}{l}0.384^{* * *} \\
(0.057)\end{array}$ \\
\hline Inflation & $\begin{array}{l}0.096^{* * *} \\
(0.035)\end{array}$ & $\begin{array}{l}0.054^{* * *} \\
(0.019)\end{array}$ & $\begin{array}{l}0.070^{* * *} \\
(0.021)\end{array}$ \\
\hline Industrial Production & $\begin{array}{l}0.003 \\
(0.003)\end{array}$ & $\begin{array}{l}-0.001 \\
(0.005)\end{array}$ & $\begin{array}{l}0.001 \\
(0.003)\end{array}$ \\
\hline Budget Deficit & $\begin{array}{c}-0.109 * \\
(0.066)\end{array}$ & $\begin{array}{c}-0.158^{* *} \\
(0.075)\end{array}$ & $\begin{array}{l}-0.158^{* *} \\
(0.077)\end{array}$ \\
\hline Current Account Deficit & $\begin{array}{l}-0.032 \\
(0.037)\end{array}$ & $\begin{array}{l}-0.030 \\
(0.044)\end{array}$ & $\begin{array}{l}-0.039 \\
(0.030)\end{array}$ \\
\hline$\Delta$ Debt Stock & $\begin{array}{l}-0.229 \\
(0.167)\end{array}$ & $\begin{array}{l}-0.259 \\
(0.196)\end{array}$ & $\begin{array}{l}-0.329 \\
(0.166)\end{array}$ \\
\hline VIX Index & $\begin{array}{l}- \\
-\end{array}$ & $\begin{array}{c}0.005 \\
(0.006)\end{array}$ & $\begin{array}{c}0.005 \\
(0.006)\end{array}$ \\
\hline$\Delta U S$ Interest Rate & - & $\begin{array}{l}0.494^{* * *} \\
(0.069)\end{array}$ & $\begin{array}{l}0.539 * * * \\
(0.098)\end{array}$ \\
\hline Bond Purchases & $\begin{array}{l}- \\
-\end{array}$ & $\begin{array}{l}- \\
-\end{array}$ & $\begin{array}{c}-0.002^{* * *} \\
(0.001)\end{array}$ \\
\hline QE1 & - & - & $\begin{array}{l}-0.102 \\
(0.105)\end{array}$ \\
\hline QE2 & - & $\begin{array}{l}- \\
-\end{array}$ & $\begin{array}{l}-0.075 \\
(0.080)\end{array}$ \\
\hline QE3 & - & - & $\begin{array}{l}-0.937^{* * *} \\
(0.178)\end{array}$ \\
\hline
\end{tabular}

Note: ${ }^{* *}, * *{ }^{*}$ show significance at the $1 \%, 5 \%$ and $10 \%$ confidence levels. Standard errors are reported in parentheses.

Source: Author's calculations.

Table 6 below shows the impact of QE by countries. Results show that the effect of bond purchases is significant and highest for Indonesia, Brazil and South Africa. The announcement effect of QE3 on government bond yield is strongest for Turkey, Indonesia, Colombia and Brazil. The model takes into account the heterogeneity and the results vary across countries. Significance and coefficients of the variables vary among 
countries due to several factors such as trade openness, degree of financial integration, exchange rate regime, the country's economic structure and policy responses. For instance, countries that are more financially integrated with the United States are much more likely to be influenced by the QE policies of the Federal Reserve. A more detailed analysis may be implemented in another study.

Table 6 | Impact of QE by Countries

\begin{tabular}{|l|c|c|c|c|}
\hline Country & Bond purchases & QE1 & QE2 & QE3 \\
\hline Brazil & $-0.0049^{* *}$ & 0.236 & $0.746^{* *}$ & $-1.689^{* * *}$ \\
\hline China & -0.0007 & 0.007 & -0.239 & -0.279 \\
\hline Hungary & $-0.0034^{*}$ & $0.789^{* * *}$ & 0.181 & $-1.232^{* *}$ \\
\hline Colombia & -0.0016 & $0.333^{*}$ & 0.182 & $-1.711^{* * *}$ \\
\hline Czech Republic & $0.0072^{* * *}$ & -0.246 & -0.213 & -0.210 \\
\hline Indonesia & $-0.0096^{* * *}$ & -0.536 & 0.527 & $-1.923^{* * *}$ \\
\hline Mexico & -0.0010 & $-0.455^{* * *}$ & -0.217 & $-1.339^{* * *}$ \\
\hline Malaysia & $-0.0016^{* *}$ & -0.046 & -0.206 & $-0.605^{* * *}$ \\
\hline Turkey & -0.0046 & $-1.681^{* * *}$ & 0.222 & $-2.137^{*}$ \\
\hline South Africa & $-0.0048^{* * *}$ & -0.100 & -0.172 & $-1.493^{* * *}$ \\
\hline Korea & -0.0006 & -0.266 & -0.247 & -0.299 \\
\hline Philippines & -0.0032 & 0.258 & -0.164 & -0.546 \\
\hline Poland & $0.0018^{* *}$ & 0.153 & 0.33 & $-0.651^{* * *}$ \\
\hline Thailand & $-0.0022^{* *}$ & $-0.434^{* * *}$ & -0.287 & $-0.672^{* *}$ \\
\hline India & $-0.0019^{* *}$ & $-0.470^{* * *}$ & 0.189 & $-0.639^{* * *}$ \\
\hline Singapore & 0.0007 & $-0.306^{* *}$ & $-0.166^{*}$ & $-0.724^{* * *}$ \\
\hline Taiwan & 0.0001 & 0.138 & -0.055 & $-0.409^{* * *}$ \\
\hline
\end{tabular}

Note: $* * * * *, *$ show significance at the $1 \%, 5 \%$ and $10 \%$ confidence levels.

Source: Author's calculations.

\section{Robustness Analysis}

In this part, we test the sensitivity of our baseline model with several robustness exercises. First, instead of the bond purchases variable, we use an alternative QE variable that is the ratio of bond purchases in the related period to the total amount of bonds available. Column 1 in Table 7 presents the results and shows that the alternative QE variable is also a significant determinant of government bond yields in EM economies. 
Table 7 | Robustness Analysis 1

\begin{tabular}{|c|c|c|c|c|}
\hline Explanatory variables & Model 1 & Model 2 & Model 3 & Model 4 \\
\hline Central Bank Rate & $\begin{array}{l}0.381^{* * *} \\
(0.057)\end{array}$ & $\begin{array}{l}0.376^{* * *} \\
(0.055)\end{array}$ & $\begin{array}{l}0.369^{* * *} \\
(0.058)\end{array}$ & $\begin{array}{l}0.365^{* * *} \\
(0.063)\end{array}$ \\
\hline Inflation & $\begin{array}{l}0.082^{* * * *} \\
(0.027)\end{array}$ & $\begin{array}{l}0.086^{* * *} \\
(0.030)\end{array}$ & $\begin{array}{l}0.102^{* * *} \\
(0.035)\end{array}$ & $\begin{array}{l}0.112^{* * *} \\
(0.035)\end{array}$ \\
\hline Industrial Production & $\begin{array}{l}-0.001 \\
(0.004)\end{array}$ & $\begin{array}{c}0.001 \\
(0.003)\end{array}$ & $\begin{array}{c}0.002 \\
(0.003)\end{array}$ & $\begin{array}{c}0.002 \\
(0.002)\end{array}$ \\
\hline Budget Deficit & $\begin{array}{c}-0.154^{* *} \\
(0.075)\end{array}$ & $\begin{array}{c}-0.134^{*} \\
(0.076)\end{array}$ & $\begin{array}{l}-0.114 \\
(0.075) \\
\end{array}$ & $\begin{array}{l}-0.131^{*} \\
(0.069)\end{array}$ \\
\hline Current Account Deficit & $\begin{array}{l}-0.048 \\
(0.040) \\
\end{array}$ & $\begin{array}{l}-0.061^{* *} \\
(0.026)\end{array}$ & $\begin{array}{c}-0.047^{*} \\
(0.026)\end{array}$ & $\begin{array}{c}-0.028^{*} \\
(0.029)\end{array}$ \\
\hline$\Delta$ Debt Stock & $\begin{array}{l}-0.393 \\
(0.152)\end{array}$ & $\begin{array}{l}-0.326 \\
(0.161)\end{array}$ & $\begin{array}{l}-0.294 \\
(0.186)\end{array}$ & $\begin{array}{l}-0.337 \\
(0.099)\end{array}$ \\
\hline VIX Index & $\begin{array}{c}0.005 \\
(0.006) \\
\end{array}$ & - & - & - \\
\hline VIX Index (t-1) & - & $\begin{array}{c}0.007 \\
(0.006) \\
\end{array}$ & - & - \\
\hline VIX Index (t-2) & - & $\begin{array}{l}- \\
- \\
\end{array}$ & $\begin{array}{l}-0.003 \\
(0.004) \\
\end{array}$ & - \\
\hline US Interest Rate & $\begin{array}{l}0.558^{* * *} \\
(0.101)\end{array}$ & - & - & - \\
\hline US Interest Rate (t-1) & - & $\begin{array}{l}0.724^{* * *} \\
(0.123)\end{array}$ & - & - \\
\hline US Interest Rate (t-2) & - & $\begin{array}{l}- \\
- \\
\end{array}$ & $\begin{array}{c}-0.244^{* * *} \\
(0.086) \\
\end{array}$ & $\begin{array}{l}- \\
- \\
\end{array}$ \\
\hline Bond Purchases & $\begin{array}{l}- \\
- \\
\end{array}$ & $\begin{array}{c}-0.0002 \\
(0.001) \\
\end{array}$ & $\begin{array}{c}-0.002^{* * *} \\
(0.001)\end{array}$ & $\begin{array}{c}-0.0016^{* *} \\
(0.001)\end{array}$ \\
\hline $\begin{array}{l}\text { Bond Purchases/Total } \\
\text { Bonds }\end{array}$ & $\begin{array}{l}-0.127^{*} \\
(0.065)\end{array}$ & - & - & - \\
\hline QE1 & $\begin{array}{l}-0.097 \\
(0.102) \\
\end{array}$ & $\begin{array}{l}-0.055 \\
(0.102) \\
\end{array}$ & $\begin{array}{l}-0.129 \\
(0.130) \\
\end{array}$ & $\begin{array}{l}-0.202 \\
(0.154)\end{array}$ \\
\hline QE2 & $\begin{array}{l}-0.087 \\
(0.082)\end{array}$ & $\begin{array}{l}-0.008 \\
(0.067) \\
\end{array}$ & $\begin{array}{l}-0.017 \\
(0.060)\end{array}$ & $\begin{array}{l}-0.040 \\
(0.066) \\
\end{array}$ \\
\hline QE3 & $\begin{array}{l}-1.206^{* * *} \\
(0.213)\end{array}$ & $\begin{array}{l}-1.103^{* * *} \\
(0.207)\end{array}$ & $\begin{array}{l}-0.767^{* * *} \\
(0.164)\end{array}$ & $\begin{array}{c}-0.859 * * * \\
(0.174)\end{array}$ \\
\hline
\end{tabular}

Note: ${ }^{* * *}, * *$ and ${ }^{*}$ show significance at the $1 \%, 5 \%$ and $10 \%$ confidence levels, respectively. Standard errors are reported in parentheses.

Source: Author's calculations.

In the analysis, there exists one important complication. The US bond yield and the VIX index are influenced by QE policies. Hence, QE affects government bond yields in EM economies both directly and also through lower US bond yields and lower VIX. 
As a result, quantitative easing variables in the model might not fully contain the effect of QE on EM government bond yield. If the coefficients of $\mathrm{QE}$ variables are significant, they give us a conservative estimate of the real effect of QE on EM bond yields. In order to address this problem, we first lag the VIX index and the 10-year US bond yield by one (Columns 2) and two (Column 3) periods and then we exclude them (Column 4). The main aim of this exercise is to check whether the coefficients of QE variables become larger and significance changes. However, these exercises do not have a significant effect and thus do not provide any evidence that QE variables do not fully capture the effect of QE on EM government bond yields.

Table 8 | Robustness Analysis 2

\begin{tabular}{|c|c|c|c|}
\hline Explanatory variables & Model 1 & Model 2 & Model 3 \\
\hline Central Bank Rate & $\begin{array}{l}0.376^{* * *} \\
(0.051)\end{array}$ & $\begin{array}{l}0.191^{* * *} \\
(0.059)\end{array}$ & $\begin{array}{l}0.137^{* * *} \\
(0.061)\end{array}$ \\
\hline Inflation & $\begin{array}{l}0.066^{* * *} \\
(0.019)\end{array}$ & $\begin{array}{l}0.072^{* * *} \\
(0.024)\end{array}$ & $\begin{array}{l}0.079 * * * \\
(0.030)\end{array}$ \\
\hline Industrial Production & $\begin{array}{c}0.001 \\
(0.003)\end{array}$ & $\begin{array}{c}0.001 \\
(0.005)\end{array}$ & $\begin{array}{c}0.003 \\
(0.002)\end{array}$ \\
\hline Budget Deficit & $\begin{array}{c}-0.168^{* *} \\
(0.074)\end{array}$ & $\begin{array}{c}-0.154^{*} \\
(0.092)\end{array}$ & $\begin{array}{l}-0.138 \\
(0.095)\end{array}$ \\
\hline Current Account Deficit & $\begin{array}{l}-0.039 \\
(0.044)\end{array}$ & $\begin{array}{l}-0.071 \\
(0.051)\end{array}$ & $\begin{array}{c}-0.096^{* *} \\
(0.042)\end{array}$ \\
\hline$\Delta$ Debt Stock & $\begin{array}{l}-0.176 \\
(0.191)\end{array}$ & $\begin{array}{l}-0.221 \\
(0.155)\end{array}$ & $\begin{array}{l}-0.161 \\
(0.165)\end{array}$ \\
\hline VIX Index & $\begin{array}{c}0.005 \\
(0.006)\end{array}$ & $\begin{array}{c}0.017 \\
(0.009)\end{array}$ & $\begin{array}{l}0.018^{*} \\
(0.010)\end{array}$ \\
\hline US Interest Rate & $\begin{array}{l}0.545^{* * *} \\
(0.110)\end{array}$ & $\begin{array}{l}0.580^{* * *} \\
(0.133)\end{array}$ & $\begin{array}{l}0.583^{* * *} \\
(0.131)\end{array}$ \\
\hline Bond Purchases & $\begin{array}{c}-0.003^{* * *} \\
(0.001)\end{array}$ & $\begin{array}{c}-0.0032^{* * *} \\
(0.001)\end{array}$ & $\begin{array}{c}-0.0036^{* * *} \\
(0.001)\end{array}$ \\
\hline MBS Purchases & $\begin{array}{c}0.001 \\
(0.001)\end{array}$ & - & $\begin{array}{l}- \\
-\end{array}$ \\
\hline QE1 & $\begin{array}{l}-0.078 \\
(0.078)\end{array}$ & $\begin{array}{c}-0.188^{* *} \\
(0.093)\end{array}$ & $\begin{array}{c}-0.196^{* * *} \\
(0.093)\end{array}$ \\
\hline QE2 & $\begin{array}{l}-0.026 \\
(0.097)\end{array}$ & $\begin{array}{l}-0.100 \\
(0.068)\end{array}$ & $\begin{array}{l}-0.055 \\
(0.071)\end{array}$ \\
\hline QE3 & $\begin{array}{c}-1.253^{* * *} \\
(0.212)\end{array}$ & $\begin{array}{c}-1.219 * * * \\
(0.271)\end{array}$ & $\begin{array}{c}-1.669^{* * *} \\
(0.354)\end{array}$ \\
\hline
\end{tabular}

Note: ${ }^{* *},{ }^{* *}$ and ${ }^{*}$ show significance at the $1 \%, 5 \%$ and $10 \%$ confidence levels, respectively. Standard errors are reported in parentheses.

Source: Author's calculations. 
In addition to bond purchases, we can also analyse the impact of mortgage-backed security (MBS) purchases by the Fed. The first model in Table 8 (Column 1) implies that MBS purchases are not a significant determinant of EM interest rates. Another complication is that some of the explanatory variables in our analysis may be endogeneous. For instance, an increase in EM government bond yield may lead to a rise in central bank policy rate, inflation and budget deficit. To solve this problem, we employ lagged variables as an instrument for presumed endogeneous variables and current variables for presumed exogeneous variables ${ }^{5}$. The results of the model in Table 8 (Column 2) show that using one lag of endogeneous variables as an instrument does not have a considerable influence on model results. Using two lags of the endogeneous variables leads to only a limited rise in the coefficient of bond purchases variable and the announcement effect of QE3 (Table 8, Column 3).

\section{Conclusion}

This study contributes to the literature by both modelling local government bond yields in emerging market economies and analysing the effect of US QE policies on EM government bond interest rates. Since we detect cross-sectional dependence and slope heterogeneity in the data, we use the Augmented Mean Group (AMG) estimator, which is robust to cross-sectional dependence and slope heterogeneity. The analysis of the heterogeneous nature of the international transmission mechanism of QE policies is a considerable contribution.

The analysis conducted shows that local government bond yields in EM economies are determined by country-specific variables, global common and QE variables. These findings are consistent with previous studies. More specifically, central bank interest rates, inflation and budget deficit in the country, 10-year US bond interest rate, announcements about the QE programmes and actual bond purchases by the Fed affect EM government bond yields significantly. The results are not homogeneous and vary by country. On average, among QE announcements only those regarding the QE3 programme are found to be a significant determinant of EM bond yields. According to the model results, MBS purchases in the US have no significant impact on EM bond yields.

The results of the study once again show the importance of global financial conditions and unconventional monetary policies implemented by the Fed for emerging market economies. We find that asset purchases by the Fed have international spillover effects and lower EM government bond yields. Future work in this area can analyse the probable declining marginal effectiveness of QE policies.

$5 \quad$ Presumed endogeneous variables are central bank interest rate, inflation rate, growth rate of industrial production and budget deficit to GDP ratio. Presumed exogeneous variables are current account deficit to GDP ratio, change in debt stock to GDP ratio, VIX index, 10-year US bond yield and QE variables. Changing the set of endogeneous variables does not have an important effect on model results. 


\section{References}

Baldacci, E., Kumar, M. (2010). Fiscal Deficits, Public Debt, and Sovereign Bond Yields. International Monetary Fund. Working Papers, 1-28, https://doi.org/10.5089/9781455202188.001

Bauer, M. D., Neely, C. J. (2014). International Channels of the Fed's Unconventional Monetary Policy. Journal of International Money and Finance, 44, 24-46, https://doi.org/10.1016/j. jimonfin.2013.12.007

Bond, S., Eberhardt, M. (2013). Accounting for Unobserved Heterogeneity in Panel Time Series Models. Nuffield College, University of Oxford.

Bowman, D., Londono, J. M., Sapriza, H. (2015). US Unconventional Monetary Policy and Transmission to Emerging Market Economies. Journal of International Money and Finance, 55, 27-59, https://doi.org/10.1016/j.jimonfin.2015.02.016

Carrion-i-Silvestre, J. L., Castro, T. D. B., López-Bazo, E. (2005). Breaking the Panels: An Application to the GDP per Capita. Econometrics Journal, 8(2), 159-175, https://doi. org/10.1111/j.1368-423X.2005.00158.x

Chen, Q., Filardo, A., He, D., Zhu, F. (2016). Financial Crisis, US Unconventional Monetary Policy and International Spillovers. Journal of International Money and Finance, 67, 62-81, https://doi.org/10.1016/j.jimonfin.2015.06.011

Christensen, J. H., Rudebusch, G. D. (2012). The Response of Interest Rates to US and UK Quantitative Easing. The Economic Journal, 122(564), F385-F414, https://doi. org/10.1111/j.1468-0297.2012.02554.x

Chudik, A., Pesaran, M. H. (2015). Common Correlated Effects Estimation of Heterogeneous Dynamic Panel Data Models with Weakly Exogenous Regressors. Journal of Econometrics, 188(2), 393-420, https://doi.org/10.1016/j.jeconom.2015.03.007

Comelli, F. (2012). Emerging Market Sovereign Bond Spreads: Estimation and Backtesting. Emerging Markets Review, 13(4), 598-625, https://doi.org/10.1016/j. ememar.2012.09.002

Csontó, B. (2014). Emerging Market Sovereign Bond Spreads and Shifts in Global Market Sentiment. Emerging Markets Review, 20, 58-74, https://doi.org/10.1016/j. ememar.2014.05.003

D'Amico, S., King, T. B. (2013). Flow and Stock Effects of Large-Scale Treasury Purchases: Evidence on the Importance of Local Supply. Journal of Financial Economics, 108(2), 425-448, https://doi.org/10.1016/j.jfineco.2012.11.007

Eberhardt, M., Bond, S. (2009). Cross-section Dependence in Nonstationary Panel Models: A Novel Estimator. MPRA. Paper No. 17692.

Eberhardt, M., Teal, F. (2011). Econometrics for Grumblers: A New Look at the Literature on Cross-country Growth Empirics. Journal of Economic Surveys, 25(1), 109-155, https://doi.org/10.1111/j.1467-6419.2010.00624.x

Ebner, A. (2009). An Empirical Analysis on the Determinants of CEE Government Bond Spreads. Emerging Markets Review, 10(2), 97-121, https://doi.org/10.1016/j. ememar.2009.02.001

Eser, F., Schwaab, B. (2016). Evaluating the Impact of Unconventional Monetary Policy Measures: Empirical Evidence from the ECB's Securities Markets Programme. Journal of Financial Economics, 119(1), 147-167, https://doi.org/10.1016/j.jfineco.2015.06.003 
Fratzscher, M., Lo Duca, M., Straub, R. (2016). On the International Spillovers of US Quantitative Easing. The Economic Journal, 128(608), 330-377, https://doi.org/10.1111/ecoj.12435

Gagnon, J., Raskin, M., Remache, J., Sack, B. (2011). The Financial Market Effects of the Federal Reserve's Large-scale Asset Purchases. International Journal of Central Banking, 7(1), 3-43, https://doi.org/10.1016/ijcb11q1a1

Georgiadis, G., Gräb, J. (2016). Global Financial Market Impact of the Announcement of the ECB's Extended Asset Purchase Programme. Journal of Financial Stability, 26, 257-265, https://doi.org/10.1016/j.jfs.2016.07.009

Horvath, R., Voslarova, K. (2017). International Spillovers of ECB's Unconventional Monetary Policy: The Effect on Central Europe. Applied Economics, 49(24), 2352-2364, https://doi. org/10.1080/00036846.2016.1237764

Jaramillo, L., Weber, A. (2013). Bond Yields in Emerging Economies: It Matters What State You Are In. Emerging Markets Review, 17, 169-185, https://doi.org/10.1016/j. ememar.2013.09.003

Joyce, M., Lasaosa, A., Stevens, I., Tong, M. (2011). The Financial Market Impact of Quantitative Easing in the United Kingdom. International Journal of Central Banking, 7(3), 113-161, https://doi.org/10.1016/ijcb11q3a5

Joyce, M. A., Tong, M. (2012). QE and the Gilt Market: A Disaggregated Analysis. The Economic Journal, 122(564), F348-F384, https://doi.org/10.1111/j.1468-0297.2012.02552.x

Kimura, T., Small, D. H. (2006). Quantitative Monetary Easing and Risk in Financial Asset Markets. Topics in Macroeconomics, 6(1), 1-54, https://doi.org/10.2202/1534-5998.1274

Miyajima, K., Mohanty, M. S., Chan, T. (2015). Emerging Market Local Currency Bonds: Diversification and Stability. Emerging Markets Review, 22, 126-139, https://doi.org/10.1016/j.ememar.2014.09.006

Neely, C. J. (2015). Unconventional Monetary Policy Had Large International Effects. Journal of Banking \& Finance, 52, 101-111, https://doi.org/10.1016/j.jbankfin.2014.11.019

$\mathrm{Ng}, \mathrm{S}$. , Perron, P. (2001). Lag Length Selection and the Construction of Unit Root Tests with Good Size and Power. Econometrica, 69(6), 1529-1554, https://doi. org/10.1111/1468-0262.00256

Peiris, S. J. (2010). Foreign Participation in Emerging Markets' Local Currency Bond Markets. International Monetary Fund. Working Papers No. 1-19, https://doi.org/10.5089/9781451982602.001

Pesaran, M. H. (2004). General Diagnostic Tests for Cross Section Dependence in Panels. Institute for the Study of Labor, No. 1240.

Pesaran, M. H. (2006). Estimation and Inference in Large Heterogeneous Panels with a Multifactor Error Structure. Econometrica, 74(4), 967-1012, https://doi. org/10.1111/j.1468-0262.2006.00692.x

Pesaran, M. H. (2007). A Simple Panel Unit Root Test in the Presence of Crosssection Dependence. Journal of Applied Econometrics, 22(2), 265-312, https://doi.org/10.1002/jae.951

Pesaran, M. H., Shin, Y., Smith, R. P. (1999). Pooled Mean Group Estimation of Dynamic Heterogeneous Panels. Journal of the American Statistical Association, 94(446), 621-634, https://doi.org/10.2307/2670182

Pesaran, M., Smith, R. (1995). Estimating Long-run Relationships from Dynamic Heterogeneous Panels. Journal of Econometrics, 68(1), 79-113, https://doi. org/10.1016/0304-4076(94)01644-F 
Pesaran, M. H., Yamagata, T. (2008). Testing Slope Homogeneity in Large Panels. Journal of Econometrics, 142(1), 50-93, https://doi.org/10.1016/j.jeconom.2007.05.010

Pesaran, H., Ullah A., Yamagata T. (2008). A Bias-adjusted LM Test of Error Crosssection Independence. Econometrics Journal, 11(1), 105-127, https://doi.org/10.1111/j.1368-423X.2007.00227.x

Potjagailo, G. (2017). Spillover Effects from Euro Area Monetary Policy Across Europe: A Factoraugmented VAR Approach. Journal of International Money and Finance, 72, 127-147, https://doi.org/10.1016/j.jimonfin.2017.01.003

Oda, N., Ueda, K. (2007). The Effects of the Bank of Japan's Zero Interest Rate Commitment and Quantitative Monetary Easing on the Yield Curve: A Macro-Finance Approach. The Japanese Economic Review, 58(3), 303-328, https://doi.org/10.1111/j.1468-5876.2007.00422.x

Szczerbowicz, U. (2015). The ECB Unconventional Monetary Policies: Have They Lowered Market Borrowing Costs for Banks and Governments? International Journal of Central Banking, 11(4), 91-127, https://doi.org/10.1016/ ijcb15q5a3

Tillmann, P. (2016). Unconventional Monetary Policy and the Spillovers to Emerging Markets. Journal of International Money and Finance, 66, 136-156, https://doi.org/10.1016/j.jimonfin.2015.12.010

Uribe, M., Yue, V. Z. (2006). Country Spreads and Emerging Countries: Who Drives Whom? Journal of International Economics, 69(1), 6-36, https://doi.org/10.1016/j. jinteco.2005.04.003

Wright, J. H. (2012). What Does Monetary Policy Do to Long-term Interest Rates at the Zero Lower Bound? The Economic Journal, 122(564), F447-F466, https://doi.org/10.1111/j.1468-0297.2012.02556.x 